\title{
PENGARUH PENGAWASAN DAN KONDISI KERJA TERHADAP KETERLIBATAN KERJA KARYAWAN RUMAH SAKIT MATA UNDAAN SURABAYA
}

The Effect of Supervision and Working Condition on Employee Job Involvement of Undaan Eye Hospital Surabaya

Fitri Widyacahya ${ }^{1}$, Ratna Dwi Wulandari²

1,2Departemen Administrasi dan Kebijakan Kesehatan, Fakultas Kesehatan Masyarakat, Universitas Airlangga, Indonesia

E-mail: widya_fitri99@yahoo.com

\begin{abstract}
Preliminary survey result showed the employee job involvement rate of Rumah Sakit Mata Undaan Surabaya reached $65.26 \%$. It meant that employee job involvement rate was low (standard $80 \%$ ). Job involvement consist of three factors there are support from co-workers, employee participation in decision making, and the dependence of the tasks. The aim of this study was to analyze the influence supervision and working condition to employee job involvement. Observational analysis was used in this research with the cross sectional design. The data was obtained through questionnaire with simple random sampling involving 62 employees as the sample of the research. The obtained data were analyzed using logistic regression test univariate $(\alpha=0.05)$ to examine the influence of supervision and working condition toward the employee's job involvement. The test result indicated that supervision significantly influenced employee job involvement at significance value was 0.000201. Better supervision made better employee job involvement. On the other hand, working condition did not influence the employee job involvement (significance value was 0.097), but cross tabulation result indicated that better working condition made better employee job involvement. It can be concluded that supervision affects job involvement while working condition does not affect the job involvement.
\end{abstract}

Keywords: job involvement, supervision, working condition

\section{ABSTRAK}

Hasil studi pendahuluan menunjukkan tingkat keterlibatan kerja karyawan di Rumah Sakit Mata Undaan sebesar $65,26 \%$. Tingkat keterlibatan kerja karyawan tersebut termasuk kategori rendah (standar $80 \%$ ) Keterlibatan kerja diukur berdasarkan tiga indikator antara lain dukungan dari kelompok kerja, partisipasi karyawan dalam pengambilan keputusan, dan ketergantungan tugas. Tujuan dari penelitian ini adalah menganalisis pengaruh pengawasan dan kondisi kerja terhadap keterlibatan kerja karyawan. Penelitian ini merupakan penelitian observasional dengan desain cross sectional. Data diperoleh melalui kuesioner dengan simple random sampling yang melibatkan 62 karyawan sebagai sampel penelitian. Data yang diperoleh dianalisis dengan menggunakan uji regresi logistik univariat $(\alpha=0,05)$ untuk menguji pengaruh dari supervisi dan kondisi kerja terhadap keterlibatan kerja karyawan. Hasil uji menunjukkan bahwa pengawasan secara signifikan memengaruhi keterlibatan kerja karyawan dengan nilai signifikansi sebesar 0,000201. Semakin baik supervisi maka semakin tinggi tingkat keterlibatan kerja karyawan. Disisi lain, kondisi kerja tidak berpengaruh terhadap keterlibatan kerja karyawan dengan nilai signifikansi 0,097, tetapi hasil tabulasi silang menunjukkan bahwa semakin baik kondisi kerja maka semakin tinggi tingkat keterlibatan kerja karyawan. Dengan demikian dapat disimpulkan bahwa pengawasan berpengaruh terhadap keterlibatan kerja, sedangkan kondisi kerja tidak berpengaruh terhadap keterlibatan kerja karyawan.

Kata Kunci: keterlibatan kerja, pengawasan, kondisi kerja

\section{PENDAHULUAN}

Keterlibatan kerja adalah ukuran seorang karyawan secara psikologis terhadap pekerjaannya dan memandang bahwa kinerja yang dilakukan sebagai ukuran harga diri (Robbins, 2008). Keterlibatan kerja karyawan memiliki dampak besar bagi organisasi. Keterlibatan kerja yang tinggi dapat memberikan pengaruh kuat terhadap organisasi dan hal tersebut dapat berpengaruh pula pada keberhasilan organisasi dalam mencapai tujuan
(Rotenberry \& Moberg, 2007). Keterlibatan kerja karyawan diharapkan mampu memberikan dampak positif bagi organisasi dengan meningkatkan kinerja karyawan didalamnya.

Terdapat beberapa faktor penyebab terjadinya keterlibatan kerja karyawan antara lain karakteristik personal, karakteristik situasional, dan hubungan individu dengan lingkungan (Rabinowitz \& Hall, 1977). Faktor yang dapat memengaruhi keterlibatan kerja meliputi dukungan dari kelompok kerja, partisipasi dalam pengambilan keputusan, 
dan ketergantungan tugas (Scott, et al., 2003). Keterlibatan kerja dipengaruhi oleh kualitas kehidupan kerja (Chandramohan, 2008). Kualitas kehidupan kerja adalah permasalahan utama yang perlu diperhatikan di dalam organisasi (Lewis, et al., 2001). Kualitas kehidupan kerja dipengaruhi oleh beberapa faktor yaitu pengawasan, tunjangan, kondisi kerja, dan desain kerja (Werther \& Davis, 2002). Keempat komponen tersebut harus dapat dipenuhi oleh organisasi untuk menciptakan kualitas kehidupan kerja yang baik. Pengawasan dan kondisi kerja merupakan bagian dari kualitas kehidupan kerja yang berupaya agar tujuan yang telah ditetapkan organisasi dapat terwujud dengan efektif dan efisien. Pengawasan adalah kegiatan dalam memantau kinerja karyawan sesuai standar untuk mengukur kinerja, memastikan kualitas dalam penerapan penilaian kinerja dan pengumpulan informasi yang dapat dijadikan sebagai umpan balik pencapaian hasil yang selanjutnya dikomunikasikan kepada karyawan (Mathis \& Jackson, 2006).

Kondisi kerja merupakan suatu kondisi yang berada di sekitar lingkungan karyawan dalam bekerja dan dapat berpengaruh terhadap diri karyawan dalam melaksanakan segala aktivitas di tempat kerja (Siagian, 2002). Karyawan dapat melaksanakan aktivitas pekerjaan secara optimal apabila kondisi di lingkungan kerja maupun di sekitar diri karyawan dapat mendukung kinerja karyawan sehingga memberikan dampak positif terhadap segala aktivitas yang dilakukan karyawan.

Rumah Sakit Mata Undaan Surabaya merupakan Rumah Sakit khusus tipe B yang telah terakreditasi paripurna oleh Komite Akreditasi Rumah Sakit (KARS). Rumah Sakit Mata Undaan Surabaya telah berupaya untuk melaksanakan pengelolaan sumber daya manusia. Namun, terdapat hal yang belum dilaksanakan adalah pengukuran terkait tingkat keterlibatan kerja karyawan didalamnya. Berdasarkan studi pendahuluan diperoleh hasil bahwa keterlibatan kerja karyawan di Rumah Sakit Mata Undaan Surabaya pada bulan Maret 2017 adalah sebesar $65,26 \%$. Menurut Teori Pareto terdapat aturan $80 / 20$ yang berarti bahwa $80 \%$ masalah muncul karena 20\% penyebab (Chinchuluun, et al., 2008). Dengan demikian dapat disebutkan bahwa tingkat keterlibatan kerja karyawan di Rumah Sakit Mata Undaan Surabaya termasuk kategori rendah sebesar $65,46 \%$ pada Maret 2017 . Penelitian ini dilakukan untuk menguji pengaruh pengawasan dan kondisi kerja terhadap keterlibatan kerja karyawan. Hasil dari penelitian ini diharapkan dapat dijadikan sebagai masukan bagi Rumah Sakit Mata Undaan Surabaya untuk meningkatkan keterlibatan kerja karyawan.

\section{METODE}

Jenis penelitian ini tergolong dalam penelitian observasional analitik dan bersifat cross sectional. Teknik pengumpulan data dilakukan dengan menggunakan instrumen berupa kuesioner. Kuesioner telah dilakukan uji validitas dan uji reliabilitas pada 20 karyawan. Penelitian ini memiliki dua macam variabel antara lain variabel independent dan variabel dependent. Variabel independent adalah pengawasan dan kondisi kerja sedangkan variabel dependent adalah keterlibatan kerja karyawan. Setiap variabel independent dilakukan uji pengaruh terhadap keterlibatan kerja dengan menggunakan regresi logistik univariat dengan nilai $(\alpha<0,05)$.

Populasi penelitian ini adalah karyawan tetap Rumah Sakit Mata Undaan Surabaya. Besar populas dalam penelitian ini adalah sebanyak 172 karyawan. Berdasarkan hasil perhitungan dengan rumus simple random sampling diperoleh sampel penelitian sejumlah 62 karyawan tetap. Data primer dalam penelitian ini diperoleh berdasarkan hasil pengisian kuesioner oleh karyawan mengenai pengawasan, kondisi kerja, dan keterlibatan kerja karyawan. Instrumen kuesioner berisi 5 pertanyaan tentang pengawasan, 6 pertanyaan tentang kondisi kerja, dan 9 pertanyaan mengenai keterlibatan kerja karyawan. Kuesioner diisi oleh responden sesuai dengan kondisi yang dirasakan di Rumah Sakit Mata Undaan Surabaya. Penilaian responden pada kuesioner menggunakan skala likert 1 sampai 4 dengan pilihan jawaban sangat tidak setuju, tidak setuju, setuju, dan sangat setuju. Jumlah skor dari pilihan jawaban responden selanjutnya dikategorikan. Kategori hasil keterlibatan kerja yaitu rendah $(9 \leq x \leq 18)$, cukup $(18<x \leq 27)$, dan tinggi $(27<x \leq 36)$. Kategori hasi penilaian pengawasan yaitu kurang $(5<x \leq 10)$, cukup $(10<x \leq 15)$, dan baik $(15<x \leq 20)$. Kategori hasil penilaian kondisi kerja yaitu kurang $(6<x \leq 12)$, cukup $(12<x \leq 18)$, dan baik $(18<x \leq 24)$.

\section{HASIL DAN PEMBAHASAN}

\section{Keterlibatan Kerja Karyawan}

Keterlibatan kerja adalah hubungan antar karyawan di dalam organisasi (Scott, et al., 2003). Keterlibatan kerja didefinisikan sebagai ukuran sejauh mana karyawan terlibat dalam pekerjaan dan ikut serta dalam proses penentuan keputusan (Khan, et al., 2011). Keterlibatan kerja adalah derajat karyawan dikenal dalam pekerjaannya, berpartisipasi aktif di dalam tempat bekerja, dan memandang prestasi penting untuk dirinya (Davis \& Newstrom, 1995). Karyawan yang mempunyai tingkat keterlibatan kerja tinggi maka akan memihak jenis terhadap pekerjaan yang dilakukan dan memiliki kepedulian yang tinggi terhadap jenis pekerjaan tersebut. Karyawan yang memiliki tingkat keterlibatan tinggi dalam pekerjaan dapat dilihat dengan adanya kepedulian tinggi terhadap pekerjaan, adanya perasaan terikat secara psikologis terhadap pekerjaan dan keyakinan yang kuat terhadap kemampuan dirinya untuk menyelesaikan pekerjaan (Robbins, 2001). Karyawan yang memiliki keterlibatan kerja rendah akan menimbulkan rasa kurang memihak terhadap pekerjaan yang dilakukan sehingga cenderung untuk melakukan pekerjaan secara rutinitas.

Tingkat keterlibatan kerja yang tinggi membuat karyawan secara menerus meningkatkan prestasi di dalam pekerjaan sehingga dapat berdampak pada perputaran karyawan yang rendah. Sedangkan karyawan yang memiliki tingkat keterlibatan kerja 
Tabel 1. Hasil Pengukuran Indikator Keterlibatan Kerja Karyawan dan di Rumah Sakit Mata Undaan Surabaya Tahun 2017

\begin{tabular}{lcrr}
\hline Indikator & Kategori & Frekuensi & Persentase (\%) \\
\hline \multirow{4}{*}{ Dukungan dari kelompok kerja } & Rendah & 1 & 1,6 \\
& Cukup & 56 & 90,3 \\
& Tinggi & 5 & 8,1 \\
\cline { 2 - 4 } & Total & 62 & 100,0 \\
\hline \multirow{3}{*}{ Partisipasi dalam pengambilan keputusan } & Rendah & 4 & 6,5 \\
& Cukup & 53 & 85,5 \\
& Tinggi & 5 & 8,1 \\
\cline { 2 - 4 } Ketergantungan tugas & Total & 62 & 100,0 \\
& Rendah & 1,6 \\
& Cukup & 56 & 90,3 \\
& Tinggi & 5 & 8,1 \\
\cline { 2 - 4 } & Total & 62 & 100,0 \\
\hline
\end{tabular}

rendah lebih besar keinginannya untuk meninggalkan organisasi dan/atau menurunkan kinerja di dalam organisasi serta melakukan pekerjaan dengan tantangan lebih besar di luar bidang pekerjaannya (Rotenberry \& Philip, 2007). Keterlibatan kerja, partisipasi karyawan, dan interdependensi tugas didukung dengan situasi kerja yang baik sehingga dapat meningkatkan produktivitas kerja, fleksibilitas karyawan, dan kepuasan karyawan (Scott, et al., 2003). Indikator pengukuran keterlibatan kerja karyawan terdiri atas dukungan dari kelompok kerja, partisipasi dalam pengambilan keputusan, dan ketergantungan tugas. Keterlibatan kerja disebabkan oleh dukungan dari kelompok kerja, partisipasi karyawan dalam pengambilan keputusan, dan ketergantungan tugas (Scott, et al., 2003). Pada tabel 1 dijelaskan mengenai hasil pengukuran tiap indikator keterlibatan kerja.

Tabel 1 menunjukkan bahwa sebagian besar responden memiliki tingkat keterlibatan kerja dalam kategori cukup terhadap indikator keterlibatan kerja. Mayoritas responden menilai jika diantara 3 indikator keterlibatan kerja sebanyak 90,3\% responden menyatakan bahwa mereka memperoleh dukungan yang cukup dari kelompok kerja. Tingkat keterlibatan kerja karyawan di Rumah Sakit Mata Undaan Surabaya akan semakin tinggi apabila aspek dukungan dari kelompok kerja, partisipasi dalam pengambilan keputusan, dan ketergantungan tugas semakin besar.

Dukungan dari kelompok kerja merupakan bentuk kepedulian yang diberikan rekan kerja kepada kelompok kerja sehingga dapat menjadikan suasana menyenangkan dalam lingkungan kerja dan terwujud kepuasan bagi karyawan dalam melaksanakan pekerjaan (Scott, et al., 2003). Kelompok kerja yang mendukung akan menjadikan suasana kerja menjadi menyenangkan, selain itu didukung dengan perilaku pemimpin sebagai faktor penentu kepuasan kerja (Luthans, 1998). Dukungan dari rekan kerja yang rendah dapat menimbulkan ketidakpuasan karyawan dalam bekerja. Apabila karyawan saling mendukung dalam melaksanakan pekerjaan akan mengurangi ketidakpuasan karyawan dalam bekerja. Dengan demikian dapat berpengaruh pula pada tingkat keterlibatan kerja karyawan.

Berdasarkan Tabel 1 dapat diketahui bahwa mayoritas karyawan menilai bahwa partisipasi dalam pengambilan keputusan termasuk dalam kategori cukup sebesar $85,5 \%$. Partisipasi karyawan dalam pengambilan keputusan merupakan bentuk keterlibatan kerja karyawan dalam proses mengambil keputusan (Spector, 1997). Terdapat unsur kepemimpinan dalam proses pengambilan keputusan karena pengambilan keputusan merupakan bagian dari tugas seorang pemimpin (Werther \& Davis, 1993). Tingkat partisipasi karyawan dalam pengambilan keputusan tinggi apabila karyawan dilibatkan dalam memberikan usulan tentang pekerjaan, dilibatkan secara aktif dalam pengambilan keputusan, dan adanya kesempatan untuk terlibat dalam pengambilan keputusan dapat meningkatkan rasa memiliki dan komitmen terhadap pekerjaan.

Hasil penilaian mengenai ketergantungan tugas sebagaimana tertera pada Tabel 1 dapat diketahui bahwa mayoritas karyawan memiliki ketergantungan tugas yang cukup sebesar $90,3 \%$. Ketergantungan tugas adalah tingkat untuk mengukur interaksi yang dirasakan karyawan dalam organisasi dan dengan karyawan lain dalam melaksanakan tugas (Pearce \& Gregersen, 1991). Karyawan merasa dalam melaksanakan tugasnya dikerjakan secara bersama dengan karyawan lain maka akan menjadikan pekerjaannya sebagai hal yang penting. Terdapat indikator pengukuran ketergantungan tugas yaitu kerja sama antar karyawan, koordinasi antar karyawan, dan konsultasi antar karyawan (Scott, et al., 2003).

Tingkat keterlibatan kerja karyawan diperoleh berdasarkan perolehan skor dari penilaian karyawan pada indikator keterlibatan kerja. Tabel 2 menunjukkan bahwa mayoritas karyawan menilai bahwa tingkat keterlibatan kerja termasuk dalam kategori cukup sebesar $88,7 \%$. Sebagian besar karyawan menilai bahwa pengawasan di Rumah Sakit Mata Undaan Surabaya tergolong dalam kategori cukup sebesar $71,0 \%$. Berdasarkan hasil pada Tabel 2 dapat diketahui pula bahwa mayoritas karyawan menilai 
Tabel 2. Hasil Penilaian Keterlibatan Kerja Karyawan, Pengawasan, dan Kondisi Kerja di Rumah Sakit Mata Undaan Surabaya Tahun 2017

\begin{tabular}{lccc}
\hline \multicolumn{1}{c}{ Variabel } & Hasil & Jumlah (orang) & Persentase (\%) \\
\hline \multirow{2}{*}{ Keterlibatan kerja } & Cukup & 55 & 88,7 \\
& Baik & 7 & 11,3 \\
\multirow{2}{*}{ Pengawasan } & Cukup & 44 & 71,0 \\
& Baik & 18 & 29,0 \\
\multirow{2}{*}{ Kondisi Kerja } & Cukup & 39 & 62,9 \\
& Baik & 23 & 37,1 \\
\hline
\end{tabular}

Tabel 3. Tabulasi Silang antara Pengawasan dan Kondisi Kerja dengan Keterlibatan Kerja Karyawan di Rumah Sakit Mata Undaan Surabaya Tahun 2017

\begin{tabular}{|c|c|c|c|c|c|c|}
\hline \multirow{3}{*}{ Variabel Independen } & \multicolumn{4}{|c|}{ Keterlibatan kerja } & \multirow{2}{*}{\multicolumn{2}{|c|}{ Total }} \\
\hline & \multicolumn{2}{|c|}{ Cukup } & \multicolumn{2}{|c|}{ Tinggi } & & \\
\hline & $n$ & $\%$ & $\mathrm{n}$ & $\%$ & $\mathbf{N}$ & $\%$ \\
\hline \multicolumn{7}{|l|}{ Pengawasan } \\
\hline Cukup & 43 & 97,7 & 1 & 2,3 & 44 & 100 \\
\hline Baik & 12 & 66,7 & 6 & 33,3 & 18 & 100 \\
\hline Total & 55 & 88,7 & 7 & 11,3 & 62 & 100 \\
\hline \multicolumn{7}{|l|}{ Kondisi Kerja } \\
\hline Cukup & 39 & 100 & 0 & 0 & 39 & 100 \\
\hline Baik & 16 & 69,6 & 7 & 30,4 & 23 & 100 \\
\hline Total & 55 & 88,7 & 7 & 11,3 & 62 & 100 \\
\hline
\end{tabular}

kondisi kerja di Rumah Sakit Mata Undaan Surabaya termasuk kategori cukup sebesar $62,9 \%$.

Tabel 3 menunjukkan bahwa karyawan yang memberikan penilaian pengawasan dalam kategori cukup dengan keterlibatan kerja yang tinggi adalah sebesar $2,3 \%$. Sedangkan karyawan yang memberikan penilaian terhadap pengawasan dalam kategori baik dengan keterlibatan kerja tinggi adalah sebesar $33,3 \%$. Berdasarkan hal tersebut dapat disimpulkan bahwa semakin baik pengawasan maka dapat menjadikan keterlibatan kerja karyawan semakin tinggi.

Tabel 3 menunjukkan bahwa karyawan yang memberikan penilaian kondisi kerja dalam kategori cukup dengan keterlibatan kerja tinggi adalah sebesar $0 \%$. Sedangkan karyawan yang memberikan penilaian terhadap kondisi kerja dalam kategori baik dengan keterlibatan kerja dalam kategori tinggi adalah sebesar 30,4\%. Dengan demikian dapat disimpulkan bahwa kondisi kerja yang semakin baik maka semakin tinggi tingkat keterlibatan kerja karyawan.

\section{Hasil Pengukuran Pengawasan dan Kondisi Kerja}

Hasil pengukuran penerapan pengawasan dan kondisi kerja diperoleh berdasarkan penilaian karyawan terhadap kedua variabel tersebut. Hasil penilaian karyawan terhadap pengawasan dan kondisi kerja dikelompokkan menjadi dua kategori yaitu cukup dan baik. Tabel 6 menunjukkan bahwa sebagian besar karyawan menilai pengawasan di Rumah Sakit Mata Undaan Surabaya termasuk dalam kategori cukup adalah sebesar $71 \%$. Hasil tersebut diperoleh berdasarkan penilaian karyawan atas kemampuan pengawasan yang dilakukan oleh pengawas atau manajer. Kemampuan yang dimaksud meliputi bertindak adil dan bijaksana, mampu menempatkan karyawan secara tepat pada setiap pekerjaan, mampu berkomunikasi yang baik dengan karyawan, mampu memberikan perhatian dan penghargaan kepada karyawan dalam pekerjaan, dan mampu mengarahkan karyawan dalam melaksanakan tugas dengan baik.

Kegiatan pengawasan adalah proses pengawas atau manajer dapat memastikan segala aktivitas aktual sesuai dengan yang direncanakan (Stoner, 2002). Manajer dan supervisor harus mampu melaksanakan penilaian secara jujur dan obyektif sehingga karyawan tidak ada yang merasa dirugikan (Nawawi, 2006). Kegiatan supervisi dipercaya dapat dijadikan sebagai salah satu cara untuk melaksanakan penilaian kinerja yang dilakukan dengan jujur dan obyektif.

Terdapat enam macam kemampuan yang perlu dimiliki oleh pengawas antara lain kemampuan teknis, kemampuan hubungan antar manusia, kemampuan administrasi, kemampuan konseptual, kemampuan politik, dan kemampuan kecerdasan emosional. Kemampuan teknis yang dimaksud adalah kemampuan dalam melaksanakan pekerjaan, kemudian kemampuan hubungan antar manusia merupakan kemampuan dalam bekerja sama dengan orang lain. Selanjutnya, kemampuan administrasi adalah kemampuan dalam merencanakan, mengatur, mengoordinasikan suatu kegiatan yang dilaksanakan dengan cara kerja tim. Kemudian, kemampuan konseptual adalah kemampuan dalam memperoleh, menafsirkan, dan menggunakan informasi yang 
dibutuhkan untuk mengambil keputusan. Kemampuan politik yang dimaksud adalah kemampuan mengetahui suatu kegiatan dapat dilakukan dengan baik di luar jalur formal. Terakhir yaitu kemampuan kecerdasan emosional, merupakan kemampuan dalam diri pengawas dalam mengelola emosi dengan baik (Leonard \& Hilgert, 2004).

Pengawasan di Rumah Sakit Mata Undaan Surabaya dalam kategori cukup perlu mendapat perhatian agar mendukung dalam peningkatan keterlibatan kerja karyawan. Pengawasan dapat menjadi lebih baik dengan melakukan upaya peningkatan kemampuan pengawas atau manajer dalam mengawasi kinerja karyawannya.

Berdasarkan tabel 6 dapat diketahui bahwa mayoritas responden menilai bahwa kondisi kerja di Rumah Sakit Mata Undaan Surabaya dalam kategori cukup sebesar $62,9 \%$. Hasil penilaian tersebut berdasarkan kondisi kerja yang dirasakan oleh responden. Pengukuran kondisi kerja meliputi penerangan di tempat kerja, suhu udara di tempat kerja, penggunaan warna di dinding ruangan, fasilitas perlengkapan kerja, hubungan antar karyawan, dan hubungan atasan dengan karyawan. Adanya teori Pareto yang menyebutkan aturan $80 / 20$ yang berart $80 \%$ masalah (cacat) ditimbulkan oleh $20 \%$ penyebab (Chinchuluun, et al., 2008). Maka dengan hasil pengukuran menunjukkan sebesar $62,9 \%$ kategori cukup, pihak manajemen Rumah Sakit Mata Undaan Surabaya perlu memberikan perhatian khusus pada kondisi kerja.

\section{Pengaruh Pengawasan terhadap Keterlibatan Kerja Karyawan}

Berdasarkan hasil cross tabulation menunjukkan bahwa semakin baik pengawasan maka semakin tinggi tingkat keterlibatan kerja karyawan. Hasil uji statistik deskriptif didukung dengan hasil uji pengaruh. Pengaruh pengawasan terhadap keterlibatan kerja karyawan diperoleh berdasarkan hasil uji regresi logistik univariat. Hasil uji pengaruh menunjukkan bahwa signifikansi atau $p$-value pada pengawasan sebesar 0,000201 yang berarti lebih kecil dari a $(0,05)$. Dengan demikian menunjukkan Ho ditolak yang berarti bahwa terdapat pengaruh antara variabel pengawasan terhadap keterlibatan kerja karyawan. Nilai Exp. (B) pada pengawasan adalah sebesar 0,023 yang digunakan untuk menunjukkan kuatnya pengaruh terhadap keterlibatan kerja. Nilai Exp. (B) sebesar 0,023 berarti kemungkinan karyawan yang menilai pengawasan termasuk dalam kategori tingg akan memiliki keterlibatan kerja yang tinggi adalah sebesar 43,48 $(1 / 0,023)$ kali lebih besar dibandingkan dengan karyawan yang menilai pengawasan dalam kategori cukup. Hasil penemuan ini mendukung penelitian sebelumnya. Terdapat hubungan antara supervisi dan keterlibatan kerja (Rabinowitz \& Hall, 1977). Hasil penelitian oleh Kim et al. (2014) menunjukkan bahwa terdapat pengaruh supervisi terhadap keterlibatan kerja karyawan.

Pengawasan berpengaruh terhadap keterlibatan kerja menunjukkan bahwa pihak manajemen sebagai pengawas atau manajer telah melaksanakan peran dengan baik. Peran yang dimaksud merupakan kemampuan yang dimiliki oleh pengawas antara lain menempatkan karyawan secara tepat sesuai dengan pekerjaan, berkomunikasi yang baik dengan karyawan, dan mampu mengarahkan karyawan dalam melaksanakan tugas dengan baik. Pengawas yang telah memiliki kemampuan tersebut terbukti dapat memberikan dampak positif terhadap keterlibatan kerja karyawan.

Pengawasan merupakan kegiatan memantau segala aktivitas karyawan untuk menjaga organisasi agar tetap berjalan menuju pencapaian tujuan dan mengevaluasi apabila diperlukan (Siagian, 2003). Pengawasan dapat pula dikatakan sebagai kegiatan pengendalian terhadap pelaksanaan perencanaan sesuai dengan tujuan atau menyimpang dari tujuan yang telah ditetapkan. Apabila terdapat penyimpangan, pihak manajemen dapat memberikan arahan untuk melaksanakan perbaikan kinerja agar standar perencanaan tidak semakin menyimpang dari hasil ketika pelaksanaan. Pihak manajemen Rumah Sakit Mata Undaan Surabaya dapat melaksanakan pengawasan yang efektif untuk mengatur pekerjaan karyawan agar terlaksana dengan baik. Dengan demikian, pengawasan yang baik akan memengaruhi tingkat keterlibatan kerja karyawan.

\section{Pengaruh Kondisi Kerja terhadap Keterlibatan kerja Karyawan}

Hasil statistik deskriptif dengan cross tabulation menunjukkan bahwa semakin baik kondisi kerja maka tingkat keterlibatan kerja karyawan semakin tinggi. Hasil statistik deskriptif didukung dengan hasil uji pengaruh. Uji pengaruh kondisi kerja terhadap keterlibatan kerja dilakukan dengan menggunakan uji regresi logistik yang menunjukkan bahwa signifikansi atau $p$-value pada kondisi kerja adalah sebesar 0,097 yang berarti bahwa lebih besar dari a $(0,05)$. Signifikansi atau $p$-value pada kondisi kerja menunjukkan bahwa Ho diterima yang berarti bahwa tidak terdapat pengaruh antara kondisi kerja terhadap keterlibatan kerja karyawan. Hasil penelitian ini didukung oleh penelitian yang dilakukan oleh Hulin dan Blood (1968) dimana kondisi kerja tidak berpengaruh terhadap keterlibatan kerja karyawan. Namun, berlawanan dengan hasil penelitian Permarupan et al. (2013) yang menyebutkan bahwa kondisi kerja berpengaruh terhadap keterlibatan kerja karyawan. Kondisi kerja yang mendukung menjadikan karyawan mudah dalam melaksanakan tugas dan memberikan perasaan nyaman dalam bekerja. Karyawan memiliki kepedulian terhadap lingkungan kerja, baik untuk kenyamanan sendiri maupun untuk memudahkan dalam mengerjakan pekerjaan yang baik (Robbins, 1999). Kondisi lingkungan kerja meliputi kondisi lingkungan kerja fisik dan non-fisik (Sendarmayanti, 2005). Kondisi kerja karyawan sebaiknya dikelola pihak manajemen dengan baik agar tercipta rasa aman karyawan dalam bekerja, kondisi kerja yang dimaksud antara lain penerangan dan suhu udara yang tepat, kebisingan yang bisa dikendalikan, penggunaan warna, ruang gerak yang dibutuhkan dan keamanan karyawan dalam bekerja (Afandi, 2016). Lingkungan kerja yang kondusif secara fisik meliputi penerangan cukup, tempat kerja bersih, nyaman, fasilitas memadai dan sebagainya, maupun kondisi nonfisik meliputi hubungan yang 
harmonis dan saling menghargai antar karyawan maupun karyawan dengan atasan dapat berpengaruh terhadap motivasi dan menciptakan kinerja karyawan meningkat (Nawawi, 2006). Dengan demikian pihak manajemen perlunya meningkatkan kondisi kerja yang mendukung karyawan dalam melakukan pekerjaan sehingga dapat berdampak positif terhadap keterlibatan kerja karyawan.

\section{SIMPULAN}

Berdasarkan hasil uji pengaruh dapat disimpulkan bahwa pengawasan berpengaruh terhadap keterlibatan kerja karyawan. Semakin baik pengawasan maka tingkat keterlibatan kerja akan semakin tinggi. Sedangkan kondisi kerja tidak berpengaruh terhadap keterlibatan kerja karyawan, tetapi hasil penelitian menunjukkan semakin baik kondisi kerja maka semakin tinggi tingkat keterlibatan kerja karyawan. Peningkatan keterlibatan kerja dapat dilakukan dengan meningkatkan kemampuan pengawas antara lain mampu bertindak adil dan bijaksana, mampu menempatkan karyawan secara tepat pada tiap pekerjaan, mampu berkomunikasi yang baik dengan karyawan, mampu memberikan perhatian dan penghargaan kepada karyawan dan mampu mengarahkan karyawan dalam melaksanakan tugas dengan baik. Selanjutnya keterlibatan kerja dapat ditingkatkan dengan memperhatikan kualitas kondisi kerja berkaitan dengan penerangan di tempat kerja, suhu udara di tempat kerja, penggunaan warna di dinding ruangan, fasilitas perlengkapan kerja, hubungan antar karyawan, dan hubungan atasan dengan karyawan.

\section{DAFTAR PUSTAKA}

Afandi, P. 2016. Concept dan Indikator Human Resource Management for Management Research. Yogyakarta: Deepublish Publisher.

Chandramohan. 2008. Human Resource Management. New Delhi: APH Publishing Corporation.

Chinchuluun, A., Pardalos, P.M., Migdalas, A. \& Pitsoulis, L. 2008. Pareto Optimality, Game Theory and Equilibria. New York: Springer.

Davis, K. \& Newstrom. 1995. Perilaku dalam Organisasi. Jakarta: Erlangga.

Hulin, C.L. \& Blood, M.R. 1968. Job Enlargement, Individual Differences and Worker Responses. Psychological Bulletin, 69, pp. 41-55.

Kim, D.H. et al. 2015. The Effects of Emotion and Communication on Job Involvement. Indian Journal of Science and Technology, 8(S5), pp. 1-5.

Leonard, E.C. \& Hilgert, R.L. 2004. Supervision, Concepts and Practices Management. 9 penyunt. Ohio: Thomson Learning.
Lewis, D. et al. 2001. Extrinsic and Intrinsic Determinants of Quality of Work Life. Scopus Journal, 14(2), pp. 9-15.

Luthans, F. 1998. Organizational Behavior. 8 penyunt New York: McGraw-Hill.

Mathis, R.L. \& Jackson, J.H. 2006. Human Resource Management. Jakarta: Salemba Empat.

Nawawi, H. 2006. Evaluasi dan Manajemen Kinerja di Lingkungan Perusahaan dan Industri. Yogyakarta: Gajah Mada University Press.

Pearce, J. L. \& Gregersen, H. B. 1991. Task Independence and Extrarole Effects of Felt Responsibility. Journal of Applied Psychology, 76(6), pp. 838-844.

Permarupan, P.Y., Abdullah, A.M. \& Roselina, A.S 2013. Quality of Work Life on Employees Job Involvement and Affective Commitment Between the Public and Private Sector in Malaysia. Asian Social Science, Volume 9.

Rabinowitz, S. \& Hall, D. 1977. Organizational Research on Job Involvement. Psychological Bulletin, pp. 265-288.

Robbins, S.P. 1999. Perilaku Organisasi Konsep Kontroversi, Dan Aplikasi. Jakarta: Prenhallindo.

Robbins, S.P. 2001. Perilaku Organisasi. 8 penyunt. Jakarta: Prentice Hall.

Robbins, S.P. 2008. Perilaku Organisasi. Jakarta: Salemba Empat.

Rotenberry, P.F. \& Moberg, P.J. 2007. Assessing The Impact of Job Involvement on Performance. Proquest Health Management Journals.

Scott, D., Bishop, J.W. \& Chen, X. 2003. An Examination of the Relationship of Employee Involvement Job Satisfaction, Employee Cooperation, and Intention to Quit in US Invested Enterprise in China. The International Journal of Organizational Analysis, 11(1), pp. 3-19.

Sendarmayanti. 2005. Manajemen Sumber Daya Manusia. Bandung: PR. Refika Aditama.

Siagian, S.P. 2002. Kiat Meningkatkan Produktivitas Kerja. Jakarta: Rineka Cipta.

Siagian, S.P. 2003. Teori dan Praktek Kepemimpinan. Jakarta: Rineka Cipta.

Spector. 1997. Job Satisfaction: Application Assessment, Causes, and Consequence. USA: Sage Publications, inc.

Stoner, J.A.F. 2002. Perilaku dalam Organisasi. Jakarta: Erlangga.

Werther, W.B \& Davis, K.1993. Human Resources and Personnel Management. New York: McGrawHill.

Werther, W.B. \& Davis, K. 2002. Human Resources and Personnel Management. Singapore: McGrawHill. 